\title{
A Argüição de Descumprimento de Preceito Fundamental e o Horizonte Interpretativo da Constituição
}

\author{
Cardos eAntonio de eAlmeida elleto
}

Procurador do Estado de Mato Grosso e Professor de Direito da UFMT e ESMAGIS/MT.

\section{SUMÁRIO}

I - Introdução: interpretação e aplicação do direito;

II - Semiótica jurídica, interpretação e horizonte interpretativo: uma proposta;

III - Horizonte interpretativo e constituição;

IV - A argüição de descumprimento de preceito fundamental;

$V$ - Argüiç̧ão de descumprimento de preceito fundamental e horizonte interpretativo;

Conclusões.

\section{I - Introdução: interpretação e aplicação do direito}

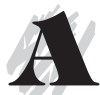
interpretação é uma questão tão antiga quanto o homem. A partir do momento que se encontra diante do mundo, surge a necessidade de interpretálo. Vivendo da utilização e emprego de diversas linguagens (falada, escrita, gestual, simbólica e tantas outras), todas elas sujeitas ao domínio do vago e do complexo, o homem se vê compelido a desenvolver técnicas e métodos capazes de auxiliarem na busca do sentido. Surge a hermenêutica, aqui entendida, como definição de trabalho, no sentido apontado por PAUL RICOEUR: a teoria das operações da compreensão em sua relação com a interpretação dos textos. ${ }^{1}$

Podemos dizer, genericamente, que a hermenêutica sugere o processo de tornar compreensíveis determinados textos (inicialmente teológicos, depois filosóficos, literários e outros). As raízes mais profundas

1 Interpretação e Ideologias, trad. Hilton Japiassu, 4. ed., Rio de Janeiro: Francisco Alves, 1990, p. 17. 
da palavra hermenêutica são encontradas no verbo grego hermeneuein, normalmente traduzido por "interpretar", e no substantivo hermeneia, significando "interpretação".

A palavra é associada ao deus-mensageiro-alado grego Hermes, a quem eram atribuídas a descoberta da linguagem e da escrita, instrumentos que a compreensão humana emprega para chegar ao significado das coisas e para transmiti-lo aos seus semelhantes. Hermes (Mercúrio para os romanos) era o intérprete da vontade dos deuses, ganhando complexidade através dos tempos, quando passou a ser, ao mesmo tempo, civilizador, patrono da ciência e imagem exemplar dos conhecimentos ocultos, sendo aquele que transmite toda a ciência secreta. Assimilado ao deus egípcio Tot, mestre da escritura, é considerado, mais tarde, deus da palavra e da inteligência, mago terrível e patrono dos magos, surgindo posteriormente como Hermes Trismegisto, ou seja "Hermes três vezes Máximo", sobrevivendo, através do hermetismo e da alquimia, até o século XVII. ${ }^{3}$

A idéia de tornar compreensível, associada a Hermes, no sentido de ser ele mediador e portador de uma mensagem, está presente implicitamente nos três significados básicos de hermeneuein e hermeneia, em seu uso antigo:
1 = exprimir em voz alta, isto é, "dizer";

2 = explicar, como quando se explica uma situação;

3 = traduzir, como na tradução de uma língua estrangeira. ${ }^{4}$

Desta raiz brotou o termo hermetismo, como sinônimo de alquimia, designando a doutrina filosófica (filosofia hermenêutica) contida em alguns textos místicos, de origem incerta, que apareceram no século I d.C., atribuídos a Hermes Trismegisto, que foram traduzidos para o latim por MARSÍLIO FICINO, em 1471. Além destes textos, os alquimistas da Idade Média atribuíam a Hermes a Tabula Smaragdima, publicada pela primeira vez em 1541, que passou a figurar, desde então, em todos os tratados de alquimia..$^{5}$ Assim, hermetismo e hermético passam a designar qualquer coisa difícil ou acessível apenas àquele que possua a chave para interpretá-la.

Em extenso verbete sobre HermesMercúrio, seguindo suas pistas no trajeto do imaginário ocidental da Antigüidade até os tempos modernos, ANTOINE FAIVRE 6 observa que alguns traços deste personagem são constantes, chegando até nossos dias. Dentre eles destaca sua função de guia, ligada a sua extrema mobilidade e, por outro lado, seu domínio do discurso e da interpreta-

2 PALMER, Richard E. Hermenêutica. Trad. Maria Luísa Ribeiro Ferreira, Lisboa: Edições 70 Ltda., 1989, p. 23 e ss.

3 V. BRANDÃO, Junito. Dicionário Mítico-Etimológico. Vol. I, Petrópolis: Vozes, 1991, p. 548 e ss.

4 PALMER, Richard E., op. cit., p. 24.

5 LALANDE, André. Vocabulário Técnico e Crítico da Filosofia. Trad. Fátima Sá Correia et alii, 3. ed., São Paulo: Martins Fontes, 1999; ABBAGNANO, Nicola. Dicionário de Filosofia. Trad. Alfredo Bosi et alii, 3. ed., São Paulo: Martins Fontes, 1999.

6 In Dicionário de Mitos Literários, org. Pierre Brunel, trad. Carlos Sussekind et alii, 2. ed., Rio de Janeiro: Ed. UnB/José Olimpio Editora, 1998, p. 448/465. 
ção, garantia de um certo tipo de saber. Também informa que COURT DE GÉBELIN, fundamentando-se numa etimologia céltica, identificava em Mercúrio as palavras signo (merc) e homem (cur) e seria o personagem assinalador, o marcador, o balizador aquele que nos ajuda a interpretar a história de nossa vida individual, fornecendo-nos para tanto as referências simbólicas.

Estas duas dimensões (o domínio do discurso e da interpretação como saber e a função de balizador e marcador da interpretação), que atravessaram os tempos, apresentam-se da maior relevância para a hermenêutica jurídica.

A interpretação das normas pode ser vista como uma questão problemática ou aporética, ${ }^{7}$ isto é, uma questão que oferece mais de uma resposta e, assim sendo, não apresenta uma resposta. Por isto, pode ser questionada quanto aos métodos que utiliza e aos fins a que objetiva. Sendo assim, propor soluções únicas e gerais para as questões de interpretação apresenta-se como impossível, ao menos no plano do razoável.

As normas, com algumas exceções, fazem previsões abstratas e gerais, enquanto a realidade social se desenrola através de situações individuais e concretas. Inicialmente a tarefa interpretativa pode ser imaginada como a transformação de uma norma geral em norma individualizada e concretizada em determinadas circunstâncias. Esta passagem do abstrato para o concreto é realizada pelo emprego de diversos métodos e técnicas desenvolvidos através do tempo.

A interpretação, como busca de sentido, pode ser situada nas investigações aristotélicas acerca da dialética, como campo da opinião, destinado aos retóricos e sofistas; em oposição ao campo da verdade (apodítico), ${ }^{8}$ reservado aos filósofos. Em ARISTÓTELES, a interpretação é relativa ao estudo da relação entre os signos lingüísticos e os pensamentos e entre os pensamentos e as coisas. Através da dialética, no sentido de método de raciocínio dedutivo, a filosofia grega proporcionou um poderoso instrumento interpretativo para os juristas.

No direito romano a interpretação tem um papel central, respondendo pela sua força criadora e prática, possibilitando o aparecimento da jurisprudência (o ius dicendi dos magistrados) ${ }^{9}$ como uma das fontes principais do direito, em face de sua função de corrigir e renovar os costumes e as leis. À força crescente dos editos, acrescentou-se o poder retórico das obras doutrinárias (interpretatio) que desenvolvia e ampliava o direito escrito, embora deixando intacta a letra respectiva. ${ }^{10}$

7 Aporia significa "falta de um caminho", quer dizer, é uma situação problemática por implicar mais de uma solução, significando, ao mesmo tempo, solução nenhuma.

8 Termo que se refere ao que é demonstrável, evidente, sendo, assim, necessário e incondicionado, referindo-se à verdade propriamente dita.

9 Que produziam editos sobre matérias de sua competência a indicar como resolveriam determinadas questões. Estes editos passaram a ser denominados ius pretorium (dada a relevância dos pretores em sua formação) ou ius honorarium (emanado daqueles que desempenhavam funções públicas $=$ honores).

10 MAXIMILIANO, Carlos. Hermenêutica e Aplicação do Direito. 9. ed., Rio de Janeiro: Forense. 1980, p. 122. 
A partir do Digesto ou Pandectas (conjunto de trechos escolhidos dos jurisconsultos romanos da época clássica, aos quais o imperador dava o nome de leis) diversas formulações passam a ser feitas em matéria de interpretação, sendo sempre lembrada a de Celso: saber as leis não é reter suas palavras, mas a força (sentido) e o po$\operatorname{der}$ (alcance). ${ }^{11}$

Há uma marcada influência do Digesto e suas formulações no direito ocidental moderno, a ponto de ter sido cunhado o vocábulo pandectologia para designar o apego demasiado aos métodos romanos e à preferência pelos comentadores das compilações justinianas. ${ }^{12}$

De toda forma, a contribuição dos jurisconsultos romanos para a interpretação foi de tal monta que leva a afirmação segundo a qual eles “(...) no direito clássico empregaram métodos de interpretação ainda utilizados atualmente; interpretavam a norma consoante a interpretação gramatical ou literal; empregavam a interpretação lógica, teleológica, orientando-se pela finalidade da lei (ratio legis), pelos antecedentes que a motivaram (occasio legis). Recorreram ainda à interpretação sistemática, ao confrontar a norma interpretada com outras referentes a matérias correlatas, numa visão global e não parcial do direito. E quanto ao resultado, entendiam que a interpretação podia ser declarativa, restritiva e extensiva. Nem a integração analógica lhes foi estranha". ${ }^{13}$

No período medieval, ${ }^{14}$ ganha corpo a interpretação realizada pelos doutores e pelas assembléias populares, decrescendo o prestígio da jurisprudência, emergindo, assim, o período dos glosadores, cujos dizeres até substituíam a própria lei, prevalecendo o argumento da autoridade em detrimento da autoridade do argumento, postura encontrada em larga escala ainda hoje.

Nos séculos XVII e XVIII, o advento do racionalismo guia também o pensamento jurídico pelos princípios da razão, que devem ser investigados para ser aplicados sistematicamente, sendo sistema entendido como um meio de ordenar e classificar o conhecimento, dando-lhe segurança e fundamentação. ${ }^{15}$ Neste período, a interpretação volta diretamente aos textos, enquanto, em nome desta idéia de segurança, a opinião dos doutos só é consultada quando expresse opinião conclusiva, fundada na razão, na letra da lei e em seu no verdadeiro "espírito da lei".

O século XIX assiste à promulgação do Código de Napoleão, em 1804, e ao aparecimento da escola da exegese (o sentido normativo é procurado na vontade do legislador historicamente situada) e da escola histórica, fundada na Alemanha por

11 Scire leges non est verba earum tenere, sed vim ac potestatem. Digesto, Livro 1, Título 3, fragmento 17, mencionado por Carlos Maximiliano, op. e loc. cit.

12 MAXIMILIANO, Carlos, op. cit., p. 44/45.

13 ANDRADE, Christiano José de. Hermenêutica Jurídica no Brasil. São Paulo: RT, 1991, p. 16, citando ALVES, José Carlos Moreira. Direito Romano. Vol. I, oㅜ 69, Rio de Janeiro: Forense, 1983, p. 99/101.

14 MAXIMILIANO, Carlos, op. cit., p. 176 e ss.

15 V. FERRAZ JÚNIOR, Tércio Sampaio. Função Social da Dogmática Jurídica. São Paulo: RT, 1980, p. 39 e ss. 
SAVIGNY por volta de 1815 (destaca a importância da continuidade histórica na formação do direito: interpretar significa compreender o pensamento do legislador expresso na lei).

A partir deste ponto, a tarefa interpretativa divide-se em duas posições até hoje em confronto:

$1^{\underline{a}}-$ teoria subjetiva $=$ o sentido da norma é a vontade do legislador (mens legislatoris), devendo procurar o sentido ex tunc ( $\rightarrow$ desde então), ou seja, desde o aparecimento da norma;

$2^{a}-$ teoria objetiva $=$ o sentido da norma é encontrado na vontade da lei (mens legis), sendo a interpretação ex nunc $(\leftarrow$ desde agora), porque se deve ter em vista a situação a que a norma será aplicada.

Acerca desta questão alerta CHRISTIANO JOSÉ DE ANDRADE: ${ }^{16}$ "A polêmica entre ambas é insolúvel, inverificável e de certa conotação ideológica. Exagerada a posição subjetivista, chega-se ao despotismo e extremada a posição objetivista, chega-se ao anarquismo em hermenêutica jurídica, o que revela a dimensão política e ideológica desta".

$\mathrm{Na}$ transição para o século XX e, durante este, ganha destaque a sistematização normativa realizada pelas codificações, gerando outras orientações, como a jurisprudência dos conceitos (o sistema jurídico visto como uma unidade perfeita e acabada, desdobrando-se em conceitos e normas abstratas), jurisprudência dos interesses (o sistema é uma totalidade fechada dotada de teleologia), jurisprudência sociológica, escola da livre investigação científica, do direito livre e muitas outras.

CARLOS MAXIMILIANO ${ }^{17}$ define a aplicação do direito como o enquadramento do caso concreto na norma jurídica adequada. Assim, a aplicação visa a fazer atuar in concreto o comando normativo abstrato, tendo por objeto descobrir o modo e os meios de amparar juridicamente um interesse. Enquanto na elaboração da lei parte-se do concreto para a abstração, na sua aplicação há uma operação inversa: parte-se da lei (= abstração) para sua aplicação e concretização. ${ }^{18}$ Note-se que a expressão aplicação do direito é mais abrangente que aplicação da lei, englobando leis em sentido material, direito não-estatal, tratados etc. A partir destas premissas, MAXIMILIANO, baseando-se em autores do final do século XIX e das primeiras décadas do século XX (o italiano SABINO JANDOLI, o alemão KARL VON GAREIS e o sueco REUTERSKIOELD), propõe o seguinte roteiro para aplicação do direito: ${ }^{19}$

$=\mathrm{o}$ aplicador do direito deve examinar:

a) a norma em sua essência, conteúdo e alcance (= questio juris em sentido estrito);

16 Op. cit., p. 17/18.

17 MAXIMILIANO, Carlos. Hermenêutica e Aplicação do Direito. Rio de Janeiro: Forense, 1980, p. 06.

18 FONSECA, Antonio Carlos. "Técnica Jurídica e Função Criadora da Jurisprudência" In Rev. Inf. Leg. Sen. Fed., no 75, p. 148.

19 MAXIMILIANO, Carlos, cit., p. 07/08. 
b) o caso concreto, suas circunstâncias e provas (= questio facti);

c) a adaptação do preceito à hipótese em apreço pressupõe:

- crítica $=$ autenticidade e constitucionalidade;

- interpretação = determinação do sentido e alcance;

- suprimento de lacunas $=$ se for $\mathrm{o}$ caso;

- examinar a ocorrência de ab-rogação (revogação total) ou de derrogação (revogação parcial), além de indagar acerca da autoridade das disposições expressas relativamente ao espaço e ao tempo.

roteiro proposto pelo ex-ministro do STF, cuja obra citada tornou-se um clássico de consulta obrigatória na matéria, ${ }^{20}$ continua válido. Contudo, a dinâmica das relações sociais impôs novas exigências à tarefa interpretativa, exigindo que novos enfoques fossem desenvolvidos a fim de fazer frente aos recentes e significativos desafios.

$\mathrm{Na}$ trilha aberta por SÓCRATES ("as verdadeiras questões não se esgotam nas respostas") interpretar, como manifestação da leitura do mundo, nunca se exaure em apenas uma e única possibilidade interpretativa, embora constitua ato único, plenamente carregado de subjetividade: "interpretar consiste, necessariamente, em apresentar uma leitura construída a partir do texto". Isto quer dizer que a ambigüidade e a vaguidade das expressões fazem com que subsista sempre algo inassimilável, por um lado, e indisível ou intransmissível, por outro; uma vez que sempre existirá alguma coisa de imprópria, de inadequada e de figurada nas palavras e símbolos utilizados, por mais que se queira e premedite em contrário, como sempre se pretende qualquer discurso/mensagem, pois a completude e clareza são valores altamente preconizados. É neste sentido que a realidade não se reduz ao que pode ser visto. Identifica-se também ao que pode ser dito. ${ }^{21}$

Todavia, não havendo um perfeito “espelhamento do real”, graças à virtualidade semântica dos objetos e discursos/ mensagens, e, por outro viés, não podendo ser creditada a plurissignificação à mera fabulação subjetiva dos indivíduos envolvidos, pode-se procurar o sentido do dizer, na mímese ficcional em particular e nos textos em geral, na afinidade entre sujeito e objeto, que recebe outra roupagem em se tratando da busca do sentido e alcance da norma jurídica.

Quanto às relações entre texto e realidade, há inúmeras abordagens (fenomenológica, estrutural, genética, histórica, analítica etc.) que nunca conseguem exaurir o sentido dos enunciados, restando de tudo que a significação jamais é una, unívoca e monossignificativa. Contrariamente, tudo conduz à idéia antônima, embora o pensamento que existe um único e

20 A primeira edição de Hermenêutica e Aplicação do Direito é de 1924.

21 JAPIASSU, Hilton. Paul Ricouer: filósofo do sentido. Apresentação de Interpretação e Ideologia, Paul Ricoeur, Rio de Janeiro: Francisco Alves, 1990, p. 01 
exclusivo sentido persista na prática cotidiana, restando apenas como figuração a lembrança da plurissignificação quando nos deparamos com as situações concretas.

$\mathrm{Da}$ idéia de mimesis (ARISTÓTELES), significando "imitação" ou "representação", passando por verossimilhança, ficção, ilusão, mentira, realismo, referência ou descrição, a ambigüidade dos textos denominados de "ficção" passa a ser, por extensão, atributo genérico de qualquer texto, o que se apresenta como um desafio ao intérprete, qualquer intérprete, inclusive o da norma jurídica.

Todo sentido imediato, denotativo, dogmático e literal de um texto pode ser superado, pois a própria realidade é um texto incompleto e inapreensível, esperando ser decifrado pelo engajamento ideológico do empreendedor. É preciso, pois, levar em conta, inclusive quanto à norma jurídica, que não há um sentido sacralizado, mas sentidos diferenciados pelos múltiplos pontos de vista em relação à percepção, significação, valoração e institucionalização daquilo que se oferece como objeto de interpretação.

Esta síntese entre o "real” e o possível na interpretação é destacada pelo escritor francês ANTOINE COPAGNON ${ }^{22}$ sob a forma de um télos subjetivo inafastável em qualquer interpretação/leitura do mundo e de seus textos: a leitura tem a ver com empatia, projeção, identificação. Ela maltrata obrigatoriamente o livro, adapta-o às preocupações do leitor. Na mesma medida, em relação à norma jurídica, a busca de sentido do texto está vinculada à intencionalidade buscada por seu empreendedor, seja a implementação de específicos e identificáveis interesses, seja o cumprimento da lei ou, enfim, a concretização da justiça.

A busca do sentido de um texto pode ser apresentada sob duas vertentes: a intencionalista e a antiintencionalista. Para a primeira, é imprescindível procurar no texto aquilo intencionalizado pelo autor (sua intenção clara e lúcida); enquanto a segunda entende que apenas é encontrável no texto aquilo que ele disse, independentemente de suas intenções, não existindo, assim, qualquer critério absoluto e seguro de validade interpretativa.

Da mesma forma, entre a procura do espírito da lei e a investigação da vontade do legislador, chegando às posições mais abertas, relacionadas com a intencionalidade do intérprete no ato interpretativo, a hermenêutica jurídica oscila na busca do sentido e alcance das expressões da norma jurídica.

Em função disto, surge a possibilidade de o operador do direito receber o rótulo de ilusionista do sentido da lei, pois, mesmo involuntariamente, o conhecimento destas peculiaridades não afasta a opção por um sentido da norma: aquele que é construído de acordo com suas convicções, seus interesses e seus compromissos ideológicos.

Ter consciência destas peculiaridades, condicionantes e limitações do ato interpretativo é fundamental para se aventurar no universo hermenêutico e buscar o significado das normas.

22 O Demônio da Teoria: Literatura e Senso Comum, trad. Cleonice Paes Barreto Mourão, Ed. da UFMG, 2000. 
que se ensaia neste texto é uma proposta de abordagem interpretativa das normas constitucionais com base nas contribuições fornecidas pelos recentes estudos de hermenêutica constitucional e de semiótica jurídica, com ênfase na argüição de descumprimento de preceito constitucional.

\section{II - Semiótica jurídica, interpretação e horizonte interpretativo: uma proposta}

Em certa medida, a linguagem jurídica, na qual as normas estão estabelecidas, emprega a linguagem comum ou natural, podendo esta ser entendida como um sistema articulado de signos que possibilita a comunicação. CHARLES MORRIS define linguagem, no pleno sentido semiótico do termo, como qualquer conjunto intersubjetivo de veículos-signos, cujo uso é determinado por regras sintáticas, semânticas e pragmáticas. ${ }^{23}$ Para o lingüista suíço FERDINAND DE SAUSSURRE (1857/ 1913), autor da obra inaugural da moderna lingüística, ${ }^{24}$ distingue-se na linguagem (= sistema de signos expressivo de idéias) dois fatores: a língua (do fr. Langue) e a fala (do fr. Parole). A língua é um sistema de elementos vocais comuns a todos os membros de uma dada sociedade e que a todos se impõe como uma pauta ou norma definida; enquanto a fala é a atividade lingüística desempenhada pelos indivíduos. ${ }^{25}$

Em verdade, embora considerada tecnicamente uma convenção, a linguagem ou língua é uma imposição histórica (não é escolhida pela comunidade presente, que a recebe num processo temporal contínuo) e social (os indivíduos são submetidos ao seu aprendizado e à chamada norma culta, isto é, aquela que serve de referência dentro do sistema lingüístico de uma sociedade segmentada em classes, sendo, na realidade, uma variante da classe ou grupo superior e não a maneira única de se utilizar o instrumental lingüístico)..$^{26-27}$

Uma das formas de instrumentalização da linguagem é o discurso. MICHEL FOUCAULT (1926/1984), numa série de conferências realizadas na PUC/RJ, em janeiro de 1973, sob o título geral de A Verdade e as Formas Jurídicas, ${ }^{28}$ refere-se ao discurso como um conjunto de fatos lingüísticos ligados entre si por regras sintáticas de construção, lembrando que a descoberta das leis e regularidades internas da

23 Apud SCHAFT, Adam, Introdução à Semântica Trad. Célia Neves. Rio de Janeiro: Civilização Brasileira, 1968, p. 309.

24 Curso de Lingüística Geral, publicada postumamente, em 1916, por seus discípulos CHARLES BALLY e ALBERT SECHEHAYE, partindo de anotações de aulas dadas entre 1909 e 1911.

25 SAUSSURE, Ferdinand de. Curso de Lingüística Geral. Trad. Antônio Chelini e outros, São Paulo: Cultrix, 1972. p. 15 e ss.

26 V. BAGNO, Marcos. Preconceito Lingüístico - o que é, como se faz. São Paulo: Edições Loyola, 1999.

27 Em relação a isto, 0 art. 13 da Constituição da República de 1988 estabelece que a língua portuguesa é o idioma oficial da República Federativa do Brasil e a Portaria MEC nº 36, de 28.01.1959, recomenda a adoção Nomenclatura Gramatical Brasileira (NGB) no ensino programático da língua portuguesa, tendo sido alterada pela Lei Federal no 5.765, de 18.12.1971.

28 Utilizei a edição do texto preparada pelos professores do Departamento de Filosofia e pelo Departamento de Letras da PUC/RJ, a partir das gravações das conferências - $2^{a}$ reimpressão da 4. ed., 1991, trad. Roberto Cabral de Melo Machado e Eduardo Jardim Morais, PUC/RJ, Divisão de Intercâmbio e Edições. 
linguagem possibilitou um enfoque não mais sob o aspecto lingüístico do discurso, mas, principalmente em função das pesquisas anglo-americanas, como jogos (games), jogos estratégicos de ação e de reação, de pergunta e resposta, de dominação e esquiva, como também de luta, preconizando como um dos eixos de pesquisa o discurso como conjunto regular de fatos lingüísticos em determinado nível, e polêmico e estratégico em outro. ${ }^{29}$

Em termos gerais, discurso pode ser entendido como uma maneira de construir sentidos que influenciam e organizam as ações dos homens e as concepções que eles têm deles mesmos e do mundo. Como integrantes do discurso, os signos são estudados pela semiótica ou semiologia. Os precursores da semiótica são encontrados na tradição médica, como HIPÓCRATES $(460 / 377$ a.C.) e GALENO DE PÉRGAMO (139/199 a.C.). O primeiro, distinguiu entre sintoma e doença, propondo uma tríplice ação médica: diagnóstico, prognóstico e tratamento. Em sua obra Prognóstico descreveu a face de um doente, preconizando que esta é a primeira coisa que o médico deve observar detidamente: "estabelece os traços de uma face extremamente doente, sua cor, suas formas, seus movimentos, e os compara com um rosto sadio. Podemos ver neste texto um precursor dos estudos semióticos". ${ }^{30}$ Por seu tur- no, o médico Galeno referia-se à diagnóstica como "a parte semiótica da medicina". ${ }^{31} \mathrm{Na}$ medicina, atualmente, o termo semiótica ou foi abandonado ou substituído por sintomatologia.

Considerando o vasto campo de atuação da semiótica (que cobre desde a semiótica da arquitetura até a biossemiótica), alertando não haver consenso entre os estudiosos quanto à sua definição, WINFRIED NÖTH ${ }^{32}$ conceitua a disciplina como "a ciência dos signos e dos processos significativos (semiose) na natureza e na cultura", ou seja, enquanto a semiótica estuda os signos, a semiose refere-se ao seu uso efetivo.

Duas denominações disputaram o nome da disciplina: semiologia, termo ligado à lingüística de FERDINAND DE SAUSSURE, sendo empregado por diversos semioticistas, como LOUIS HJELMSLEV e ROLAND BARTHES, que influenciaram a designação nos países românicos. Por outro lado, autores de língua inglesa e alemã preferiram o termo semiótica.

Observando ser a lingüística a ciência da linguagem verbal, SAUSSURE ${ }^{33}$ cogitava de uma ciência que estudasse a vida dos signos no seio da vida social, da qual a lingüística seria uma parte, que estudaria os signos e que leis os regem, chamando-a semiologia (do grego semainô, significar, don-

29 Op. cit., p. 6.

30 BAITELLO JUNIOR, Norval. O Animal que Parou os Relógios: ensaios sobre comunicação, cultura e mídia. 2. ed., São Paulo: Annablume, 1999, p. 17.

31 NÖTH, Winfried. Panorama da Semiótica: de Platão a Peirce. 2. ed., São Paulo: Annablume, 1998, p. 19.

32 Op. cit., p. 17.

33 Op. cit., p. 24. 
de semeîon, "signo"). Sua proposta era o estudo das diversas linguagens naturais, destacando a função social do signo.

Nos Estados Unidos, CHARLES SANDERS PEIRCE (1839/1914) sugeriu a necessidade de construir uma teoria geral dos sistemas sígnicos, denominando-a semiótica, que se constituiria com ênfase na função lógica do signo, centrada nas práticas lingüísticas da ciência, no funcionamento da linguagem da ciência.

Em função disto, foram ensaiadas distinções conceituais: a semiologia referia-se apenas aos signos humanos, especialmente aos textuais; enquanto a semiótica designaria a ciência mais geral dos signos, incluindo os signos dos animais (linguagem coreográfica das abelhas, cantos das baleias e golfinhos etc.) e da natureza em geral. Também a semiótica foi entendida como um sistema de signos com estruturas hierárquicas análogas à linguagem (tal como uma língua, um código de trânsito, arte, música ou literatura), sendo a semiologia a teoria geral destes sistemas semióticos (HJELMSLEV e GREIMAS). Por iniciativa de ROMAN JAKOBSON, a Associação Internacional de Semiótica, em 1969, decidiu adotar semiótica como o termo geral para designar as investigações nas tradições da semiologia e da semiótica geral. ${ }^{34}$

Enfim, a semiologia ou semiótica consiste no estudo científico das propriedades dos sistemas de comunicação, sejam eles naturais ou artificiais. A primeira designação, ao lado de semasiologia, referia-se ao estudo, dentro da filosofia, dos sistemas de signos e símbolos em geral.

A semiótica é a ciência geral de todas as linguagens, ou seja, estuda em conjunto as características lingüísticas, psicológicas, filosóficas e sociológicas dos sistemas comunicativos, sendo a ciência de toda e qualquer linguagem, seja formada por palavras ou qualquer outro signo.

Seu campo de estudo foi dividido pelos filósofos CHARLES SANDERS PEIRCE (1839/1914), CHARLES MORRIS (1901/1979) e RUDOLF CARNAP (1891/1970) em três áreas:

Sintaxe = estuda as relações entre as expressões lingüísticas;

Semântica = estuda as relações entre estas expressões e os objetos do mundo exterior a que se referem ou descrevem, estuda a significação dos signos, quer lingüístico ou não;

Pragmática $=$ estuda a dependência da significação destas expressões de seus usuários (englobando a situação social em que são usadas).

Nos últimos anos, o estudo da semiótica veio a ser aplicado à análise da comunicação humana em todos os seus modos de percepção. $\bigcirc$ grau de desenvolvimento destes estudos tem variado, sendo esta abordagem adotada principalmente por antropólogos, lingüistas, psicólogos e sociólogos da cultura. Na Europa, a análise semiótica (ou semiológica) desenvolveu-se como parte da tentativa de analisar todos

34 V. NÖTH, Winfried, op. cit., p. 23/24. 
os aspectos da comunicação como sistema de sinais (sistemas semióticos), tais como a música, a alimentação, o vestuário, a dança e a língua, sendo considerável a influência de ROLAND BARTHES (1915/1980) nesta área. ${ }^{35}$

De surgimento recente, a "semiótica ainda é um território do saber e do conhecimento ainda não sedimentado, indagações e investigações em progresso". ${ }^{36} \mathrm{Tal}$ surgimento parte da verificação que a língua, como linguagem verbal oral ou escrita, não é o único modo de expressão, de manifestação de sentido nem de comunicação social.

Assim, ao lado de uma linguagem verbal, de sons que veiculam conceitos e que se articulam no aparelho fonador, recebendo esses sons no Ocidente a tradução visual alfabética (linguagem escrita), existe concomitantemente uma enorme variedade de outras linguagens (rituais de tribos indígenas, desenhos de povos antigos, danças, músicas, cerimônias, jogos, pinturas, criações arquitetônicas, hieróglifos, pictogramas, ideogramas etc.) que também se constituem em sistemas sociais e históricos de representação do mundo. ${ }^{37}$

Aplicando as noções desenvolvidas principalmente por CHARLES S. PEIRCE e CHARLES MORRIS no campo semiótico, autores como LUIS ALBERTO WARAT, TÉRCIO SAMPAIO FERRAZ JÚNIOR, JUAN-RAMON CAPELLA,
THEODOR VIEHWEG, ÓSCAR CORREAS E ANTONIO ANSELMO MARTINO, dentre outros, desenvolveram estudos aplicando a abordagem semiótica ao fenômeno jurídico, denominando-a semiótica jurídica.

Partindo dos campos de estudo da semiótica e constatando exprimir-se o direito numa linguagem técnico-jurídica, buscam os juristas estudar o direito enquanto necessita, para sua existência, da linguagem, pois o direito tem uma linguagem, por ter um sentido comunicacional, uma vez que "tem por condição de existência a de ser formulável numa linguagem, imposta pelo postulado da alteridade", segundo MARIA HELENA DINIZ, ${ }^{38}$ citando TÉRCIO SAMPAIO FERRAZ JÚNIOR.

$\bigcirc$ direito utiliza-se, então, no prisma normativo (sem, contudo, se circunscrever e se esgotar nesta dimensão), da linguagem legal ou linguagem das leis, no amplo sentido de normas jurídicas.

Aplicando as dimensões semióticas à norma jurídica teremos:

- Dimensão Sintática $=$ considera a norma em relação a outras normas do mesmo sistema jurídico, em suas possíveis formas de combinação, estabelecendo suas relações formais (coordenação e subordinação) e os processos de formação (fundamento de validade, processo legislativo) e derivação (eficácia sintática e compatibilidade vertical);

35 CRYSTAL, David. Dicionário de Lingüística e Fonética. Rio de Janeiro: Jorge Zahar Editor, 1988.

36 SANTANELLA, Lucia. O Que é Semiótica. São Paulo: Brasiliense, 1994, p. 08.

37 Idem, p. 11.

38 Compêndio de Introdução à Ciência do Direito. São Paulo: Saraiva, 1988, p. 154. 
- Dimensão Semântica $=$ considera a relação da norma com os objetos e condutas extranormativos (eficácia semântica), analisando a adequação da norma ao campo objetivo a que se refere, levando em conta não a verdade para a obtenção do semanticamente significativo, mas o critério da conveniência; ${ }^{39}$

- Dimensão Pragmática $=$ estuda a norma sob o ponto de vista do emprego que dela fazem seus intérpretes e usuários, ou seja, a norma, suas significações e seus destinatários, onde estará presente a ideologia, por integrar a tarefa hermenêutica. ${ }^{40}$

A pragmática é o âmbito do signo que "implica as relações significantes com o intérprete, com aquele que usa os signos". ${ }^{41}$ Recebe esta designação porque na filosofia de CHARLES S. PEIRCE o pragmatismo ${ }^{42}$ é um método de determinação do significado, entendido como tentativa de esclarecimento das idéias. $\bigcirc$ pragmatismo sustenta que as idéias só diferem quanto ao sentido quando acarretam uma diferença de conduta. "Na tradição semiótica de MORRIS, a pragmática é considerada como um exame dos modos de uso das mensagens, relação entre os signos e os usuários do signo". ${ }^{43}$
$\mathrm{Na}$ propositura de um modelo lingüístico pragmático para a análise da norma jurídica, FERRAZ JR. ${ }^{44}$ propõe uma relação básica entre direito e linguagem, dentre outras, calcada nos seguintes modos: o direito, enquanto fenômeno empírico, tem uma linguagem (no sentido da dicotomia langue/parole-SAUSSURE), podendo-se falar de uma linguagem do direito, preconizando levar o direito ao âmbito lingüístico, num estudo jurídico, não lingüístico, buscando investigar as normas, as características operacionais da teorização jurídica, a referência à práxis decisória, a possibilidade de solução dos conflitos, a regulamentação de comportamento etc., enfim, propõe investigar o fato lingüístico norma, tal como ele aparece na experiência discursiva do direito.

Sob determinado enfoque, inspirado em HELLER, ${ }^{45}$ a norma jurídica resulta da relação recíproca entre o dever-ser normativo (ideal) e o ser normativo (real). O ser dá forma às normas e como forma de ordenação concreta só é possível devido ao fato que seus destinatários consideram esta ordenação como algo que deve ser e o atualizam.

39 Cf. PERELMAN, Chaïm; OLBRECHTS-TYTECA, Lucie. Tratado da Argumentação: a nova retórica São Paulo: Martins Fontes, 1996.

40 MARCONDES, Danilo. "Linguagem e Ideologia”. In Filosofia, Linguagem e Comunicação, Cortez Ed., 1992.

41 RECTOR, Mônica. "Glossário de Semiótica ou Semiologia”. In Revista de Cultura Vozes, no 8, ano 68, Petrópolis: Vozes, 1974, p. 601.

42 Segundo PEIRCE, pragmatismo é a maneira como o conhecimento (saber racional) está relacionado com a ação humana ou conduta (finalidade racional). PEIRCE, C. S. Conferências sobre Pragmatismo, A. Cultural, Col. Os Pensadores, nota 3, 1974, p. 11.

43 RECTOR, Mônica, op. e loc. cit.

44 Teoria da Norma Jurídica. 2. ed., Rio de Janeiro: Forense, 1986, p. 5 a 12.

45 Hermann Heller, Teoria Del Estado, Fondo de Cultura Economica, México, trad. Luis Tobío, tercera edición, 1955, p. 267 ss. 
Na qualidade de texto, a norma jurídica é uma composição pluralística: o legislador é o primeiro intérprete da realidade e estabelece a proposição normativa (ser) através do texto (que não se confunde com a norma: texto é o sinal lingüístico, enquanto a norma é aquilo que se revela, já alertava CANOTILHO), ${ }^{46}$ enquanto o intérprete, partindo da primeira interpretação, compreende a norma, concretizando-a. Assim, legislador e intérprete compõem a norma em conjunto.

As normas, desta forma, resultam sempre da interpretação: as disposições e enunciados normativos formam o ordenamento em potência, como um conjunto de possibilidades de interpretação. Por outro lado, concretamente, como realidade atual, o ordenamento é composto de normas: conjunto de interpretações através das quais os operadores do direito dizem o que elas dizem. Assim, o legislador registra proposições e o intérprete compõe a norma.

Considerando estes fatores, toda interpretação jurídica é realizada sob a incidência de determinantes e condicionantes que atuam simultaneamente sobre a atividade do intérprete. Determinantes são os fatores relacionados ao próprio intérprete, como ideologia, visão de mundo, posição social e demais interesses que direcionam sua atividade de busca do significado das normas jurídicas. Por sua vez, as condicionantes estabelecem o horizonte interpretativo e firmam as balizas da interpretação ou, em outras palavras, condicionam os limites em que a interpretação pode estar contida.

As determinantes são insuscetíveis de controle externo, uma vez que configuram fatores aos quais apenas o próprio intérprete tem acesso pleno. Por sua vez, o controle das condicionantes pode ser exercido pelo sistema jurídico, que se encarre ga de obstruir o trânsito de interpretações que ponham em risco sua coerência e integridade. Neste sentido, as interpretações discordantes prosperam apenas na doutrina, embora, por isto, não deixem de ter relevância para o sistema, funcionando como possibilidades de mudança interpretativa.

Nas normas jurídicas em geral, o horizonte interpretativo está estabelecido no curso de suas dimensões sintática (que informa sua relação e possibilidade de combinação com as demais normas do sistema jurídico, inclusive a Constituição), semântica (que expressa a conotação e a denotação ${ }^{47}$ dos termos da norma em relação ao objeto normado) e pragmática (que busca

46 Direito Constitucional. 5. ed., Coimbra: Almedina, 1991, p. 225.

47 O termo denotativo está empregado como sentido dicionarizado e lexical das palavras, independente do modo como poderá ser empregada; enquanto conotativo expressa o sentido que varia conforme o contexto em que a palavra está inserida. Ambos exprimem as características de vaguidade e ambigüidade da linguagem: vaguidade porque na aplicação de determinados vocábulos brota a incerteza e a indeterminação. Por seu turno, a ambigüidade refere-se ao fato de as mesmas palavras poderem se referir a diferentes fatos, objetos ou propriedades (por exemplo: manga = parte de uma roupa e manga = fruta. Em face disto, impõe-se a idéia de contextualização: os signos estabelecem relações associativas (sintagmáticas), dependendo seu sentido do exame da conexão entre eles, ou seja, o valor e o sentido de cada um está na solidariedade com outros signos (dependência direta da presença de outros). 
as funções da norma dentro do sistema, estando expressa nas denominações occasio legis [antecedentes] e ratio legis [finalidade], traduzidas como axiologia e teleologia normativa). A conjugação destas dimensões estabelece e condiciona os limites da interpretação.

Em face destes fatores, uma norma pode oferecer um horizonte interpretativo extremamente estreito, ensejando uma interpretação meramente especificadora ou declaratória (quando fixa um prazo ou estabelece uma certa idade para a prática de um ato, por exemplo) ou, ao contrário, possibilitar um significativo alargamento ou o fechamento, maior ou menor, da interpretação (por exemplo, quando contém conceitos indeterminados), possibilitando uma interpretação extensiva ou restritiva.

Inspirados na proposta de tridimensionalidade da norma jurídica na atividade interpretativa desenvolvida por FRIEDRICH MÜLLER, ${ }^{48}$ podemos vislumbrar que, diante do caso concreto, o intérprete está posto diante da seguinte problemática:

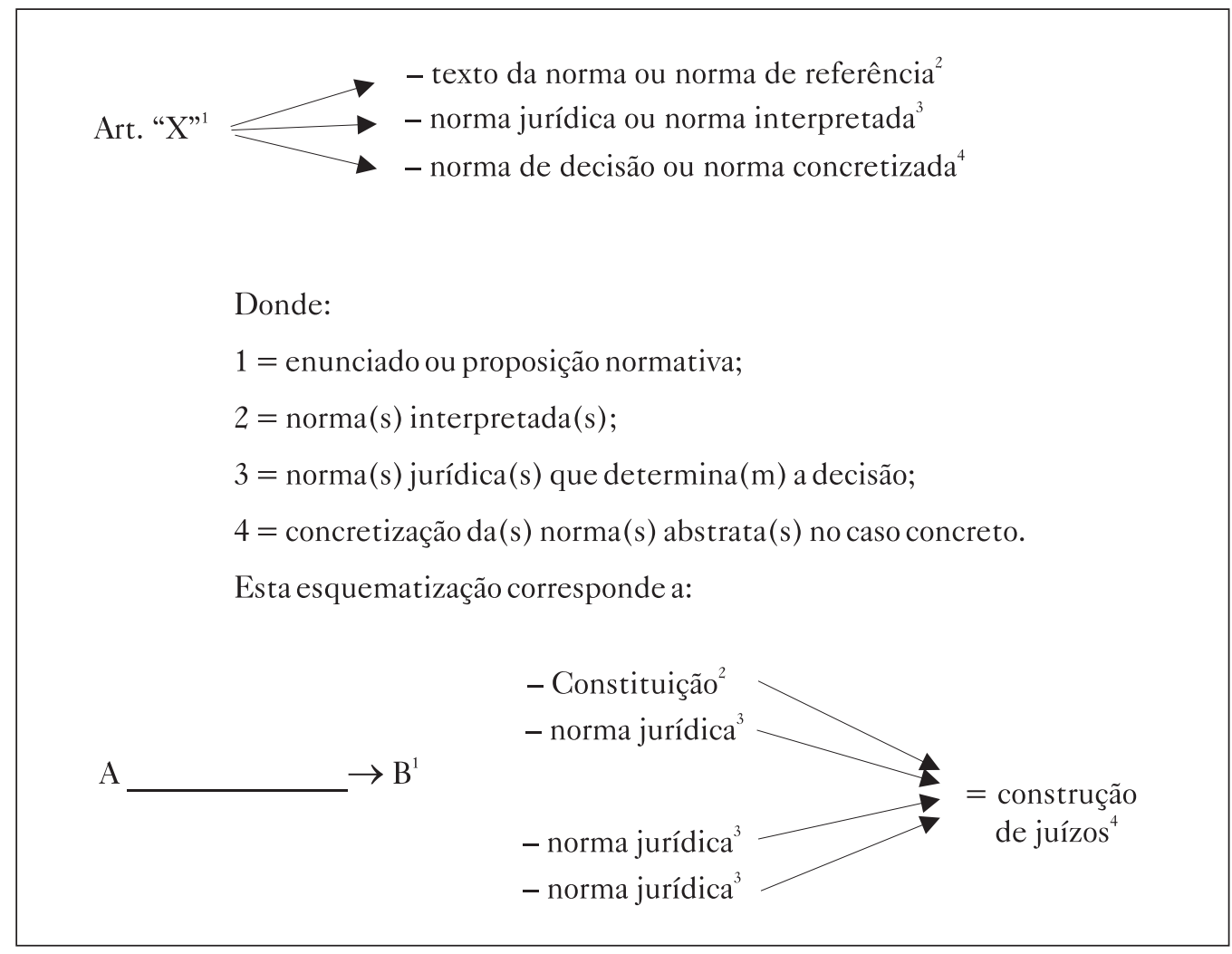

48 Juristische Methodik, Fünfte, Auflage, Duncker \& Humblot, Berlim, 1993. 


\section{Donde:}

$1=$ caso concreto;

$2=$ disposições constitucionais acerca da matéria;

3 = norma(s) jurídica(s) incidente (s);

$4=$ formulações realizadas.

O texto normativo da norma jurídica (enunciado) configura mera proposição, norma de referência, não contendo imediatamente a norma. Esta surge apenas após a tarefa interpretativa, configurando a norma a ser concretizada na hipótese que se apresenta, decidindo o caso concreto. $\mathrm{O}$ intérprete privilegiado é o magistrado, enquanto as partes e o MP também participam da tarefa interpretativa.

\section{III - Horizonte interpretativo e constituição}

A Constituição pressupõe o exercício do poder constituinte originário, que não possui limites de natureza jurídica e, assim, não é inibido nem mesmo pelo texto constitucional em vigor no momento em que está sendo exercido. Sendo impelido pela força da soberania popular, tem o condão de promover profundas e substanciais alterações no desenho da estrutura social e estatal, bem como na própria ordem jurídica, no desempenho da missão de criar um tex- to normativo que espelhe a nova idéia de direito, na designação de GEORGES BURDEAU e outros ${ }^{49}$ que substituirá a anterior, promovendo a proclamação de um novo padrão político como entendia RODOLFO SMEND, 50 edificando e hierarquizando o ordenamento jurídico.

É necessário enfatizar que o direito enquanto norma posiciona-se a reboque da realidade social: enquanto não se consolidam as mudanças provocadas pela dinâmica do processo social não tem lugar a norma jurídica que aborde os novos temas. Por ocasião das mudanças sociais, o campo jurídico da realidade é um dos últimos a conformar as novas configurações. Também é preciso destacar que outras dimensões do direito, notadamente a ciência do direito, a teoria da justiça e a sociologia jurídica, por atuarem num plano predominantemente zetético e não dogmático, acompanham de perto as alterações da realidade social em suas múltiplas significações.

Plasmada nestes termos, a Constituição pressupõe certa estabilidade sem cair no extremo da imutabilidade. $O$ ponto de equilíbrio consiste em, possibilitando que o texto constitucional seja atualizado, não sejam promovidas alterações que impliquem em destruição ou fraude da nova idéia de direito plasmada pelo constituinte originário. KARL LOEWENSTEIN dizia que a Constituição é um organismo vivo e, como

49 Droit Constitutionnel et Institutions Politiques. 12. ed., Paris: LGDJ, 1966, p. 79. Também JORGE MIRANDA dele se utiliza, Manual de Direito Constitucional, 3. ed., Coimbra Editora, 1991, para designar a concepção que informa e antecede a elaboração da norma. Entre nós, veja-se SILVA, José Afonso da. Curso de Direito Constitucional Positivo. 16. ed., São Paulo: Malheiros Editores, 1999, p. 5, que, referindo-se à Constituição de 1988, menciona uma "nova idéia de direito que informa uma concepção do Estado e da Sociedade diferente da que vigorava no regime constitucional revogado".

50 Apud Carl Schmitt, Teoria de la Constitución. Editorial Revista de Derecho Privado, Madrid, s/d, p. 187. 
tal, nunca é idêntica a si mesma, estando sempre submetida à eterna mudança de todo o vivente.

Contudo, mesmo apresentando este perfil, a supremacia da Constituição prevalece e pode ser trabalhada em nome de um processo de transformação social, pois contêm seus dispositivos normas que, mesmo internalizadas como dimensão simbólica, ${ }^{51}$ podem ser concretizadas sob o viés de um compromisso com a mudança e a emancipação.

Em virtude disto, as normas contidas no texto constitucional, embora sejam dotadas de maior ou menor efetividade e aplicabilidade, ${ }^{52}$ mas, sempre, dotadas destas qualidades, são amoldadas à visão que delas prevalece entre os operadores do direito engajados na visão jurídica predominante. $\mathrm{Na}$ mesma medida, podem ser concretizadas de outra forma, de acordo com outros compromissos teóricos.

Com isto, as relações entre o conteúdo da Constituição e a realidade social, onde se localizam seus destinatários, são necessariamente mediatizadas interpretativamente pelos operadores do direito e, imperando entre estes a visão dogmático- tradicional, o grau de eficácia e aplicabilidade de suas normas ficará comprometido com a manutenção do mundo existente, mesmo que a custo do esvaziamento de seu significado e da conservação de uma realidade profundamente injusta e indigna.

Esta situação pode ser reconhecida quando os operadores do direito passam a destilar, na interpretação da Constituição, a ideologia jurídica ${ }^{53}$ que traduz as aspirações de valores dominantes, em detrimento de leituras dos dispositivos constitucionais que proporcionem maior abertura no exercício dos direitos assegurados e promovam a adequação de suas garantias às exigências da justiça.

Contudo, na linha preconizada aqui como crítico-zetética, postula-se uma abordagem da Constituição que edifique aquela proposta emancipatória do homem e de dignificação da ordem jurídica, pois, "o direito, sim, intervem na realidade, transformando-a dentro de certos limites. Então, se o espaço jurídico é espaço de dominação, também pode ser espaço de emancipação (desde que realize e efetive os valores e

51 Emprego a expressão no sentido trabalhado por MARCELO NEVES ( $A$ Constituição Simbólica. São Paulo: Acadêmica, 1994) de supremacia do significado latente da norma em detrimento de seu significado manifesto, ou: uma hipertrofia de sua função simbólica em detrimento da concretização normativa do respectivo texto legal (p. 33). Exemplificando, apesar da função simbólica das declarações contidas nos textos constitucionais e seus preâmbulos, elas podem servir também à interpretação e, portanto, à concretização normativa do texto constitucional (idem).

52 Sobre tema, v. SILVA, José Afonso da. Aplicabilidade das Normas Constitucionais. 2. ed., São Paulo: RT, 1982.

53 O termo está empregado no sentido dado por TIGAR e LEVY: constitui um enunciado, em termos de sistema de regras legais, das aspirações, objetivos e valores de um grupo social. Os autores entendem que este sistema não é propriedade exclusiva do grupo que exerce o controle efetivo, pois os grupos que aspiram ao poder formulam ataques também em termos de sistemas de regras e princípios jurídicos, mas quando um grupo de fato exerce o poder - definido como controle efetivo sobre determinado território - sua ideologia é a lei. (TIGAR, Michael E.; LEVY, Madeleine R. O Direito e a Ascensão do Capitalismo. Trad. Ruy Jungmann, Rio de Janeiro: Zahar Editores, 1978, p. 275) 
programas estabelecidos pelo pacto fundador)". 54

$\mathrm{Na}$ interpretação das normas constitucionais, ao lado dos fatores relacionados ao próprio intérprete, que determinam uma interpretação em detrimento de outra(s), as condicionantes se manifestam principalmente através da nova idéia de direito plasmada pelo constituinte originário, expressa nos princípios adotados e nas regras estabelecidas, consistindo, em seu conjunto, no horizonte interpretativo da Constituição. Estas considerações devem ser levadas a efeito na atividade interpretativa da Constituição.

A condicionante interpretativa ressalta com maior vigor nos princípios constitucionais explícitos (como, v.g., o Preâmbulo da Constituição da República de 1988) que nos implícitos (v. art. 5ํㅗ § 2으). Entretanto, ambos não só norteiam a interpretação constitucional, condicionando-a e estabelecendo seu horizonte interpretativo, mas também vinculam o legislador infraconstitucional em todos os níveis hierárquicos de elaboração de normas jurídicas (do Poder Legislativo aos contratantes em geral, passando pela prestação jurisdicional).

Em síntese, preconiza-se, aqui, que o horizonte interpretativo da interpretação constitucional é estabelecido e condicionado pela nova idéia de direito fixada pelo constituinte originário. conceito de nova idéia de direito, neste contexto, pode ser fixado em função dos fatores históricos que conduziram à elaboração da Constituição.

Enquanto não subsiste dúvida quanto à força do exercício originário do poder constituinte, há profundas dissensões em relação ao efetivo momento histórico de exercício deste poder. Ensina CANOTILHO que há continuidade formal do direito constitucional quando uma ordem constitucional, apesar da alteração normativa, se reconduz, jurídica e politicamente, à ordem constitucional anterior. Por outro lado, ocorre descontinuidade formal quando uma nova ordem constitucional implica uma ruptura (revolucionária ou não) com a ordem constitucional anterior. Enfim, fala-se de descontinuidade formal e material quando, além da ruptura formal (descontinuidade formal) se verifica a "destruição" 55 do antigo poder constituinte por um novo, alicerçado num título de legitimidade substancialmente diferente do anterior. $^{56}$

Baseado nestas distinções, LUÍS ROBERTO BARROSO ${ }^{57}$ classifica a Constituição da República de 1988 no elenco da descontinuidade material, por haver coroado um movimento popular reivindicatório pelo qual retomou a soberania popular o poder constituinte usurpado desde 1964, asseverando: "Mais do que em qualquer outro momento na história brasileira, a

54 Filtragem Constitucional: construindo uma nova dogmática jurídica. Porto Alegre: Sergio Antonio Fabris Editor, 1999, p. 56.

55 O termo é empregado por CARL SCHMITT.

56 Direito Constitucional. Coimbra: Almedina, 1991, p. 147/149.

57 Interpretação e Aplicação da Constituição. São Paulo: Saraiva, 1996, p. 61. 
Constituição de 1988 é produto legítimo do exercício da soberania popular, com as virtudes e vícios que daí advêm, sobretudo quanto às imperfeições do sistema representativo".

Não fica dúvida que a Constituição de 1988, ultrapassados os governos militares, trabalhou como essência de nova idéia de direito a plenitude de um Estado Democrático de Direito, com todas as conseqüências oriundas desta opção jurídico-política.

Por outro lado, MANOEL GONÇALVES FERREIRA FILHO58 entende, como outros, que a Constituição de 1988 não foi obra do poder constituinte originário, mas, em face da convocação do Congresso Nacional investido de poderes especiais de reforma pela Emenda Constitucional no 26/85, resultou de uma "reforma constituinte" sem as limitações das cláusulas pétreas então vigentes (que apenas proibiam a abolição da Federação e da República), o que mais parece a descrição do exercício do poder constituinte originário com outra nomenclatura.

De toda sorte, embora alguns poucos ainda entendam estar o exercício do poder constituinte originário vinculado e adstrito apenas às grandes fraturas provocadas por processos revolucionários radicais, ${ }^{59}$ nos moldes da americana, da francesa e da soviética, por exemplo, toda ruptura na es- trutura política, econômica, social e institucional do Estado, implicando transformações de maior ou menor calibre e envergadura, mesmo que por meios pacíficos, reclama a adoção de uma nova ordem jurídica que a legitime, carecendo, assim, da edição de um novo texto constitucional, dotado de nova legitimidade, que espelhe as novas expectativas sociais.

Neste momento, isto é, no momento constituinte originário, nenhum instituto da ordem jurídica então em vigor está ao resguardo de mudanças e modificações, pois o poder originário não se compadece com o regime anterior, comprometido que está, somente, com a imposição de uma nova ordem constitucional e, conseqüentemente, jurídica, isto é, a nova idéia de direito.

A Constituição, como documento juspolítico ${ }^{60}$ possui hierarquia superior a todas as normas de um ordenamento jurídico, e, na qualidade de Lei Máxima de um sistema jurídico, dispõe sobre a estruturação e a organização do Estado, o exercício do poder político, dos direitos e garantias individuais, coletivos e sociais e das atividades concernentes à ordem cultural, econômica e social dentro de determinado território, consolidando um projeto de dominação. Ademais, a Constituição também estabelece normas sobre a criação de outras normas, na qualidade de pressuposto da produção normativa do Estado. ${ }^{61}$

58 O Poder Constituinte. 3. ed., São Paulo: Saraiva, 1999, p. 181/182.

59 Sobre o tema, v. Revolução, Constituição e Ditadura, org. Nanci Valadares de Carvalho, São Paulo: Vértice/RT, 1986; Revolução e Poder Constituinte, JOSÉ CARLOS TOSETI BARRUFINI, São Paulo: RT, 1976; O Poder Constituinte e a Revolução, RUY RUBEn RUSCHEL, Cadernos de Direito Constitucional e Ciência Política, São Paulo: RT, ano 1, no 2, jan.-mar./1993, p. 110.

60 Em seu aspecto formal, a Constituição é essencialmente um documento jurídico, enquanto seus aspectos materiais são políticos.

CANOTILHO, J. J. Gomes; MOREIRA, Vital. Fundamentos da Constituição, Coimbra Editora, 1991, p. 41. 
Esta dupla significação, jurídica e política, deve-se a sua característica de, concomitantemente, estabelecer normas jurídicas que, em resumo, ordenam e estruturam a vida estatal, além de dispor acerca de decisões políticas fundamentais para a sociedade. Em matéria constitucional, o entrelaçamento entre o político e o jurídico já fora vislumbrado por EMMANUEL SIEYÈS, em 1788, através de panfleto político célebre (O Que éo Terceiro Estado?), distinguindo, inauguralmente, poder constituinte e poderes constituídos; FERDINAND LASSALLE, em 1862, em conferência famosa (A Essência da Constituição), quando afirmava que os problemas constitucionais não são de direito, mas de poder; e por CARL SCHMITT, em 1928, em sua Teoria da Constituição, quando entendia que o político é antecedente necessário do jurídico, e o momento da decisão é o momento político de todo direito, daí conter a Constituição, como matéria essencial, decisões políticas fundamentais.

Todavia, estas decisões políticas fundamentais, integrantes da nova idéia de direito, não se bastam a si mesmas, carecendo de normas e instituições e, mormente, de interpretações que as tornem realizáveis, que possibilitem seu aparecimento na concretude do mundo. Com razão, pois, MANUEL GARCIA-PELAYO quando alerta que "tais decisões nada seriam se não se desenvolvessem em um sistema de normas e entidades concretas, e se é certo que tais normas e entidades carecem de senti- do se não estão vinculadas em relação teleológica com as ditas decisões, não é menos certo que estas só têm sentido constitucional em sua vinculação com aquelas". ${ }^{62}$

Assim, a par da efetividade e aplicabilidade de suas normas, precisa estar a Constituição imersa na realidade social a que dá contornos e configuração e da qual recebe os influxos de atualização, mudança e alteração. Dito de outra forma: o campo jurídico demarcado pela Constituição como norma superior deve, necessariamente, estar envolvido e impregnado pela realidade social que o abrange e circunscreve. De outra via, esta mesma realidade social exige transformações inadiáveis no campo jurídico, com reflexos no texto constitucional.

É justamente a relação dialética entre a Constituição e a realidade social que guarda a distância entre a folha de papel lassalleana e o sentimento constitucional ao qual se referia KARL LOEWENSTEIN e pelo qual clamam as forças transformadoras de qualquer grupo social em relação à lei superior do ordenamento jurídico. Enfim, o mínimo de distância que se pode exigir entre o dever-ser normado e o ser socialmente tido como existente.

\section{IV - A argüição de descumprimento de preceito fundamental}

A Constituição da República, ainda na versão originária, art. 102, então parágrafo

62 Derecho Constitucional Comparado. Madrid: Revista de Occidente, 1953, 3. ed., p. 111. 
único (passando a $§ 1^{\circ}$ com a EC 3, de 17 de março de 1993) incluiu dentre as competências originárias do Supremo Tribunal Federal a Argüição de Descumprimento de Preceito Fundamental (ADPF), que somente se tornou passível de ajuizamento com o advento da Lei no 9.882, de 3 de dezembro de 1999, que estabeleceu normas sobre o processo e julgamento deste instrumento da jurisdição constitucional. $\bigcirc$ instituto apresenta as seguintes características legais:

- foro: Supremo Tribunal Federal (art. $1^{\mathrm{o}}$, caput);

- trata-se de medida que tem por objeto evitar ou reparar lesão a preceito fundamental, resultante de ato do Poder Público (art. 1으 caput);

- também cabe quando for relevante o fundamento da controvérsia constitucional sobre lei ou ato normativo federal, estadual ou municipal, incluídos os anteriores à Constituição (art. 1ํㅡㄹ parágrafo único, inciso I);

- legitimidade ativa: mesmo elenco da ADIn (art. 103, C.R.) = art. 2으, I;

- Procurador-Geral da República: pela redação remanescente do $\S 1^{\mathrm{o}}$, do art. $2^{\circ}$, uma vez que o inciso II foi vetado, pode ser acionado o PGR que decidirá sobre o cabimento de seu ingresso em juízo;

- não será admitida quando houver qualquer outro meio eficaz de sanar a lesividade (art. $4^{\mathrm{o}}, \S 1^{\mathrm{o}}$ );

- do indeferimento da inicial caberá agravo, no prazo de 5 dias (art. $4^{\circ}, \S 2^{\circ}$ );

- concessão de medida liminar: por decisão de maioria absoluta (6 ministros) $=\operatorname{art} .5^{\mathrm{o}} \mathrm{e}$, em caso de extrema urgência ou perigo de lesão grave, ou ainda, em período de recesso, poderá o relator conceder a liminar, ad referendum do Tribunal Pleno (art. 5으, § $\left.1^{\mathrm{o}}\right)$;

- medida liminar: dentre outras hipóteses, poderá consistir na determinação de que juizes e tribunais suspendam o andamento de processo ou os efeitos de decisões judiciais, ou de qualquer outra medida que apresente relação com a matéria objeto da argüição de descumprimento de preceito fundamental, salvo se decorrentes da coisa julgada (art. 5을 $\S 3^{\mathrm{o}}$ );

- após a apreciação do pedido de liminar, solicitação de informações às autoridades responsáveis, num prazo de 10 dias (art. 6ㅇ);

- possibilidade de audiência de pessoas com experiência e autoridade na matéria (art. 6ํㅡㄹ $\S 1^{\circ}$ );

- possibilidade de sustentação oral e juntada de memoriais, por requerimento dos interessados no processo (art. 6을 $\S 2^{\circ}$ );

- Ministério Público: não tendo formulado a argüição, vista do processo ao MP por 5 dias, após o decurso do prazo para informações (art. 7ํㅡ, parágrafo único);

- quorum de decisão: pelo menos dois terços dos ministros (art. $8^{\mathrm{o}}$ );

- fixação de interpretação: Julgada a ação, far-se-á comunicação às autoridades ou órgãos responsáveis pela prática dos atos questionados, fixando-se as condições e o modo de interpretação e aplicação do preceito fundamental (art. 10); 
- efeitos: A decisão terá eficácia contra todos e efeito vinculante relativamente aos demais órgãos do Poder Público (art. 10, § 3º);

- possibilidade de declaração incidental de inconstitucionalidade de lei ou ato normativo: nestes casos, tendo em vista razões de segurança jurídica ou de excepcional interesse social, poderá o Supremo Tribunal Federal, por maioria de dois terços de seus membros, restringir os efeitos daquela declaração ou decidir que ela só tenha eficácia a partir de seu trânsito em julgado ou de outro momento que venha a ser fixado (art. 11);

- irrecorribilidade: a decisão julgando procedente ou não o pedido é irrecorrível, não cabendo ação rescisória (art. 12);

- caberá reclamação (v. RISTF) contra descumprimento da decisão (art. 13).

\section{V - Argüição de descumprimento de preceito fundamental e horizonte interpretativo}

Uma das questões de maior relevância na matéria contida na ADPF gira em torno do conceito de preceito fundamental decorrente da Constituição. A princípio, a delimitação da extensão do conceito poderia ser fixada considerando-se apenas as normas previstas nos arts. $1^{\circ}$ a 17 do texto constitucional, abrangendo os princípios fundamentais (arts. $1^{\mathrm{O}}$ a $4^{\mathrm{O}}$ ) e os direitos e garantias fundamentais (arts. 5 a 17).
Contudo, tal interpretação, centrada apenas na literalidade normativa, estaria condenada a estreitar sobremaneira o conteúdo do conceito, em detrimento da nova idéia de direito trabalhada pelo constituinte originário, contida na ratio do dispositivo e na matéria sob sua proteção.

Neste ponto, avulta a idéia de fundamentalidade, que qualifica os preceitos em que está fundada a argüição. Termo associado aos direitos fundamentais, seu conteúdo refere-se, segundo a designação de R. ALEXY, ${ }^{63}$ a matérias decisivamente constitutivas das estruturas básicas do Estado e da sociedade.

JOSÉ AFONSO DA SILVA, ${ }^{64}$ também examinando os direitos fundamentais, entende o qualificativo no significado de "situações jurídicas sem as quais a pessoa humana não se realiza, não convive e, às vezes, nem mesmo sobrevive; fundamentais 'do homem' no sentido de que a todos, por igual, devem ser, não apenas formalmente reconhecidos, mas concreta e materialmente efetivados". Assim, direitos fundamentais do homem significa direitos fundamentais da pessoa humana ou direitos humanos fundamentais (v. C.R./88, Título II e caput, in fine, art. 17, neste sentido). De toda sorte, a expressão direitos fundamentais do homem não deve ser entendida como esfera privada em contraposição à atividade pública, como simples limitação do Estado, mas limitação imposta pela soberania popular aos poderes constituídos do Estado que dela dependem (citando PÉREZ LUÑO).

63 Apud CANOTILHO, J. J. Gomes. Direito Constitucional. 5. ed., Coimbra: Almedina, 1991, p. 509/510.

64 Curso de Direito Constitucional Positivo. 6. ed., São Paulo: RT, 1990, p. 159. 
Apreciando a mesma matéria (direitos fundamentais) outros autores (PÉREZ LUÑO, PECES-BARBA), com pequenas diferenças, referem-se a exigências de dignidade, liberdade e igualdade da pessoa humana, enfatizando o desenvolvimento integral dos indivíduos.

Considerando a nova idéia de direito como horizonte interpretativo e as abordagens acerca da fundamentalidade, os denominados preceitos fundamentais a que se referem os termos enunciados no $\S 1^{\mathrm{o}}$, do art. 102, da Constituição da República, podem ter sua dimensão normativa fixada.

Inicialmente, observe-se que não cabe, aqui, a discussão, relativa exclusivamente aos princípios, se abrangidas as espécies explícitas e implícitas: tratando-se de preceito, refere-se unicamente às normas positivadas no texto constitucional. A despeito disto, o dispositivo está redigido de maneira a que preceito se relacione ao termo decorrente ("... preceito fundamental decorrente desta Constituição ...”), palavra que se refere à ação de originar, derivar, expressão mais adequada aos princípios que às regras.

Neste ponto, cabe lembrar as palavras de HELLER:" 65 "A Constituição normada juridicamente não consiste apenas de modo exclusivo em preceitos jurídicos autorizados pelo Estado mas também, para sua validade, precisa sempre ser complementada pelos elementos constitucionais não normados e por aqueles outros normados mas não jurídicos. (...) Por esta razão, o preceito jurídico particular só pode ser fundamentalmente concebido, de modo pleno, partindo da totalidade da Constituição política".

Assim, o conteúdo da proposição constitucional não é determinado apenas por sua literalidade, carecendo o exame de sua dimensão semântico-pragmática através do que SCHINDLER denominava cenário (Welt): fatores ambientais, culturais, antropológicos, geográficos, etnográficos, econômicos e sociais. Enfim, a totalidade da realidade social com a qual o texto constitucional deve ser posto a interagir dialeticamente.

O estudo das dimensões semântica e pragmática do enunciado da Constituição, limitado pela imposição da plenitude de um Estado Democrático de Direito como nova idéia plasmada pelo constituinte originário, estabelece, desta maneira, o elemento condicionante do horizonte interpretativo.

Isto posto, a fundamentalidade, que caracteriza as normas credenciadoras de argüição, consiste atributo sem o qual não, isto é, trata-se de normas tão marcadamente essenciais à estrutura social e estatal fixada pelo constituinte originário que, uma vez retiradas do texto, provocam incompletude, mutilando o conjunto estabelecido. Podem ser elencadas seguintes especificidades identificadoras do sentido e alcance do atributo normativo-constitucional da fundamentalidade:

a) refere-se a normas que se reportam às estruturas básicas do Estado Democrático 
de Direito que, embora estejam concentradas nos arts. $1^{\mathrm{o}}$ a 17 , não se exaurem neste elenco;

b) abrange, também, normas que disponham sobre estruturas básicas da sociedade, como família, educação, cultura e outras;

Partindo deste esboço, os preceitos fundamentais podem ser divididos em duas espécies:

$1^{\underline{a}}$ - de natureza subjetiva, quando se refere a direitos que estão relacionados à dimensão dos indivíduos, protegendo valores que consagram a vida, a liberdade e a dignidade;

$2^{\mathrm{a}}$ - de natureza objetiva, quando seu conteúdo refere-se ao interesse da coletividade e da sociedade, enfim, a valores que expressam a generalidade do interesse público.

Posta desta maneira, a extensão da fundamentalidade, como característica das normas que traçam a estrutura básica do Estado Democrático de Direito e da sociedade, poderia ser questionada, pois abrangeria praticamente todo o texto constitucional. Ao que se contrapõe o seguinte argumento: nem todas as normas constitucionais que dispõem sobre a estrutura do Estado Democrático de Direito e da sociedade são normas básicas ou, de outra forma, apenas as normas concernentes à estrutura básica do Estado e da sociedade se amoldam ao perfil de preceitos fundamentais.
Esta caracterização invoca a etimologia do qualificador fundamental, no que significa base, alicerce, suporte sobre o que se edifica toda a estrutura subseqüente. Desta forma, a tarefa do intérprete, em cada caso, seria identificar no universo normativo constitucional se a norma que contempla refere-se à estrutura do Estado ou da sociedade. Como segundo passo, deve verificar se tal norma afigura-se de base para a estrutura a que se refere.

Aqui, a questão se cruza com o conceito de constituição material: apenas configuram preceitos fundamentais aqueles que contêm normas estruturais do Estado e da sociedade nos seus aspectos fundamentais, ${ }^{66} \mathrm{ou}$ seja, questões de natureza macroestrutural, de anatomia do Estado e da sociedade, configurando a pauta mínima do texto constitucional, como normas nucleares de todo o edifício normativo estatuído na Constituição. Assim, normas básicas da organização do Estado, de formas e de exercício do poder, normas assecuratórias de direitos individuais, coletivos e sociais integram, necessariamente, a categoria.

Assim, por exemplo, em relação à organização do Poder Judiciário, configura preceito fundamental, espelhando norma básica de sua estruturação, o contido no art. 92, dando conta dos órgãos daquele Poder do Estado. Entretanto, o contido no art. 93, que descreve o conteúdo específico do Estatuto da Magistratura, ${ }^{67}$ embora configure dispositivo relativo à estrutura do Judiciário,

66 CANOTILHO, J. J. Gomes, op. cit., p. 69.

67 Embora o caput se refira a princípios que devem ser observados pela lei que tratar a matéria, os incisos contêm, em verdade, normas que não são de natureza principiológica, mas estruturante. 
não se insere no rol de norma de base, de preceito fundamental, inclusive por ser, todo ele ${ }^{68}$ composto de matéria infraconstitucional.

A ADPF tem alguns pontos de semelhança com a ação direta de inconstitucionalidade (ADIn), como o elenco de figuras com legitimidade ativa (art. 103, C.R.) e a declaração de inconstitucionalidade de lei ou ato normativo. Entretanto, dela fundamentalmente difere por ter cabimento de forma preventiva (evitar lesão a preceito fundamental) ou corretiva (para reparar a lesão provocada a este preceito), dirigindo-se contra ato do Poder Público.

Enquanto a ADIn busca expurgar do ordenamento jurídico, através da declaração de inconstitucionalidade, lei ou ato normativo contrário à Constituição; a argüição também poderá promover tal efeito, embora não seja seu objeto principal. A abrangência dos efeitos da declaração, em ambos os casos, poderá ser restringida por maioria de dois terços dos ministros do STF.

Os termos do caput do art. $1^{\mathrm{o}}$ da Lei n 9.882/99 especificam o conteúdo da ADPF, diferenciando-o em relação à ação direta de inconstitucionalidade, ao se referir a ato do Poder Público.

A despeito de algumas divergências, a noção de poder em direito público guarda a idéia de parcela da soberania do Estado que é transferida a um órgão ou entidade, justificando e legitimando a imposição de decisões de ordem política e ações de natureza administrativa.

A expressão poder público, apesar de sua extensão, tem conteúdo definido no ordenamento jurídico a partir da idéia de autoridade de dominação, sentido em que se apresenta como "delegada" do próprio Estado. Deste conceito, decorre a significação de "poder" como "competência" ou "função autorizada", que se atribui ao órgão, dentro da jurisdição que lhe é traçada. Em face desta "delegação", cada poder constituído por um órgão, desempenha ou exerce a "soberania nacional". ${ }^{69}$

Ainda nesta vertente, o poder em direito público apresenta dois sentidos: a) como órgão ou autoridade constituída para concretizar as finalidades estatais, exercendo as funções que lhe são atribuídas pela norma jurídica, sendo seu conjunto denominado poder público; b) como função a ser exercida pela autoridade ou órgão, expressando sua competência. ${ }^{70}$

Assim, os atos do poder público a que se refere a norma legal alcançam um amplo leque de atividades e autoridades, inclusive as de natureza jurisdicional. Nesta perspectiva, a ADPF cobre um campo não abrangido pela ADIn, que visa apenas leis ou atos normativos federais ou estaduais.

Desta forma, na matéria em que couber a ADPF, também caberá a ADIn; mas, quando a pretensão consistir em evitar ou

68 Talvez com as exceções dos incisos IX, X e XI.

69 SILVA, De Plácido e. Vocabulário Jurídico. Vol. III, 4. ed., Rio de Janeiro: Forense, 1975, p. 1.169.

70 Tendo como referência DE PLÁCIDO E SILVA, op. e loc. cit. 
reparar lesão oriunda de descumprimento daquele preceito fundamental, não caberá a segunda, pois esta somente pode ser ajuizada contra lei ou ato normativo federal ou estadual (art. 102, inciso I, alínea $a$ ) em face de qualquer norma constitucional, buscando sua expulsão do ordenamento jurídico, enquanto a argüição é pertinente apenas a preceitos fundamentais, à procura de prevenção ou reparação de lesão.

Em face disto, parece que o disposto no $\S 1^{\circ}$, do art. 4⿳⺈ da Lei n⿳0 9.882/99, ainda causará grandes polêmicas. Com efeito, assim dispõe a norma: "Não será admitida argüição de descumprimento de preceito fundamental quando houver qualquer outro meio eficaz de sanar a lesividade". Ora, pelo âmbito de sua abrangência, caberá ADIn sempre que uma lei ou ato normativo federal ou estadual ferir qualquer dispositivo constitucional, seja ele veiculador de preceito fundamental ou não, relembrando aqui a distinção entre texto da norma (seu sinal lingüístico) e norma (o que se revela, se designa). ${ }^{71}$ Assim, a lei ou o ato poderá provocar lesividade a preceito fundamental mas ser objeto de argüição e não de ADIn. Neste caso, será aplicado o $\S 1^{\circ}$ do art. 4을

A resposta parece estar justamente no objeto dos dois institutos, onde reside a diferença. Enquanto a ADIn busca expurgar do ordenamento jurídico, através da declaração de inconstitucionalidade, lei ou ato normativo contrário à Constituição; na ADPF o que se objetiva é a prevenção ou reparação da lesão a preceito fundamental ao questionar seu descumprimento. Portan- to, o que norteia a opção por um instituto ou outro é a pretensão que se almeja. $\bigcirc$ fato de a argüição comportar a declaração de inconstitucionalidade de lei ou ato normativo que agride dispositivo constitucional (art. 11, Lei no 9.882/99) não interfere nesta diferenciação.

Assim, quanto ao objetivo, deve ser entendido que a ADIn busca apenas a expulsão da lei ou ato inconstitucional do ordenamento jurídico, enquanto a ADPF, com a declaração de inconstitucionalidade, destina-se a pedidos de natureza preventiva e corretiva em relação aos preceitos fundamentais, buscando mais que o expurgo da norma. Esta conclusão destaca-se dos termos em que a Lei no 9.882/99 atribui a possibilidade de concessão de medida liminar para a suspensão do andamento de processos ou a suspensão dos efeitos de decisões judiciais e ainda da suspensão de qualquer outra medida que apresente relação com a matéria objeto da argüição, salvo as decorrentes da coisa julgada (art. 5으, $\S 3^{\circ}$ ), uma vez que esta é atacável apenas pela via rescisória. Quer dizer, as conseqüências da declaração de inconstitucionalidade na argüição são mais específicas, pois geradoras, também, daquelas possibilidades de suspensão.

Os termos do art. 10 da Lei n⿳0 9.882/ 99 também levam a esta conclusão: no julgamento do mérito, serão fixadas as condições e o modo de interpretação e aplicação do preceito fundamental, ou seja, a decisão preocupar-se-á mais com a fixação do conteúdo do preceito fundamental do que com 
os termos da inconstitucionalidade da lei ou ato violador.

Neste ponto, cabe perguntar se o mandado de segurança poderia fazer prevenir ou corrigir a lesão, trancando, então, o caminho para o ajuizamento da argüição. Embora a noção de direito líquido e certo esteja fixada com certa firmeza pela doutrina e pela jurisprudência, em tese não se afasta a hipótese de haver dúvida quanto ao cabimento de um ou outro remédio constitucional, afigurando-se como único norteador a noção de preceito fundamental: caberia a argüição apenas em relação a este, embora, neste caso, possa, sem embargo, ser escolhida a via mandamental.

Contudo, o grande diferencial da nova medida está contido na previsão do art. 1ํㅡㄹ parágrafo único, inciso $\mathrm{I}$, da Lei $\mathrm{n}$ o 9.882/99: "Caberá também argüição de descumprimento de preceito fundamental: I - quando for relevante o fundamento da controvérsia constitucional sobre lei ou ato normativo federal, estadual ou municipal, incluídos os anteriores à Constituição”.

Primeiramente, porque inclui o âmbito municipal nos embates entre leis e atos contrários à Constituição da República, o que está vedado no prisma da ADIn consoante farta jurisprudência do $\mathrm{STF}^{72}$ embora esta inclusão seja específica e exclusivamente em relação aos preceitos fundamentais. Por outro lado, admite que sejam questionados atos do Poder Público anteriores ao advento do texto constitucio- nal em vigor, dando grande extensão ao seu alcance, não mais adstrito à esfera da vigência da Constituição, como na ADIn, também como assentado pelo STF. ${ }^{73}$ Contudo, a efetivação destas possibilidades dependerá de como o Supremo Tribunal Federal entenderá o sentido de relevantefundamento da controvérsia constitucional, como previsto na norma.

A decisão de mérito na argüição tem eficácia erga omnes e efeito vinculante em relação aos demais órgãos do Poder Público, como dispõe o art. 10, § 3으 da Lei. Diferentemente da $\mathrm{ADC}$, cujo efeito vinculante está previsto no próprio texto constitucional (art. 102, § 2º , embora incluído pela EC 03/93 e não pelo constituinte originário), a vinculatividade das decisões definitivas de mérito na argüição está prevista na norma infraconstitucional, abrindo caminho para o questionamento da constitucionalidade desta disposição.

A questão do efeito vinculante na ADC foi amplamente debatida quando da tramitação do projeto que se transformou na EC 03, de 17 de março de 1993, inserindo o instituto no texto constitucional. $\mathrm{Na}$ quela oportunidade, em que pese o entendimento em contrário posteriormente firmado pelo STF, destacou-se a inconstitucionalidade da medida por afrontar o princípio da separação dos Poderes (art. 2º) , uma vez que coloca o STF no plano de cooperador na formulação de normas gerais e abstratas, ${ }^{74} \mathrm{O}$ contraditório (art. 5으,

72 V., v.g., RT 664/189, RDA 199/201.

73 V.g., RT 686/218, RDA 188/288 e RTJ 160/62.

74 V. ATALIBA, Geraldo. "ADC - ou como agredir o Estado de Direito", artigo publicado em Folha de São Paulo, 1ำ cad., 09.08.1993, p. 03. 
inciso LV), o devido processo legal (art. 5ํㅡ, inciso LVI), o duplo grau de jurisdição, o direito de acesso ao judiciário (art. 5ํㅜ inciso XXXV) e o juiz natural (art. $5^{\circ}$, inciso LIII), dentre outros argumentos relacionados à matriz romano-germânica do nosso sistema jurídico $^{75}$ e ao perfil autoritário do instituto. ${ }^{76}$

A despeito disto, o efeito vinculante foi introduzido no sistema constitucional vigente com a chancela do guardião da Constituição. Contudo, no caso da ADPF, a atribuição de vinculação à decisão de mérito é dada por norma de escalão infraconstitucional, manejando, no entanto, matéria de essência constitucional.

Por conferir tão grave atributo a estas decisões, a matéria da vinculação é de competência constitucional, por consubstanciar característica básica e atípica (quer dizer, extraordinária) do próprio sistema judicial, configurando, não sem certa ironia, preceito fundamental. Logo, por este prisma, a atribuição de vinculatividade às decisões definitivas na argüição de descumprimento de preceito fundamental parece estigmatizada pela mácula da inconstitucionalidade material.

Enfim, tratando de matéria de ordem pública, acredito que se aplicam também à argüição de descumprimento de preceito fundamental as mesmas regras pertinentes à $\mathrm{ADIn}$ e à $\mathrm{ADC}$ em relação à prescrição e à decadência, que não a alcançam.

\section{Conclusões}

Depois de trabalhar a idéia que legislador e intérprete compõem a norma jurídica em conjunto e que as normas resultam sempre da interpretação, a proposição aqui apresentada consiste em, sem desprezar as posturas tradicionais acerca da interpretação das normas constitucionais, mas fugindo da idéia de sagração dos conteúdos normativos, formular o conceito de horizonte interpretativo, tomando por base a nova idéia de direito plasmada pelo constituinte originário, distinguindo entre condicionantes e determinantes, e explorá-lo, principalmente, em relação à ADPF. Quanto a esta, propõe um conceito de norma veiculadora de preceito fundamental, estabelecendo suas especificidades e estabelecendo sua tipologia. Assim, em face do apresentado, podem ser oferecidas as seguintes conclusões:

1. a hermenêutica, considerada através da história, exibe duas dimensões: domínio do discurso/interpretação e balizadora/marcadora da própria interpretação;

2. a interpretação das normas consiste em questão problemática ou aporética: não apresenta uma resposta, podendo ser questionada quanto aos métodos que utiliza e aos fins a que objetiva;

3. a hermenêutica jurídica fornece as chaves e os instrumentos indispensáveis à compreensão e à extensão dos princípios e normas do direito;

75 Cujos princípios basilares são o livre convencimento do magistrado e o princípio da legalidade.

76 Em relação a este último argumento, v. GRAU, Eros Roberto. "Efeito Vinculante e Totalitarismo", Folha de São Paulo, 22.11. 1998, $1^{\circ}$ cad., Tendências e Debates, p. 3. 
4. a tarefa interpretativa pode ser imaginada como a transformação de uma norma geral e abstrata em norma individualizada e concretizada em determinadas circunstâncias, dando-se esta passagem do abstrato para o concreto através de diversos métodos e técnicas;

5. é preciso levar em conta que não há um sentido consagrado e intocável, mas sentidos diferenciados pelos múltiplos pontos de vista em relação à percepção, significação, valoração e institucionalização daquilo que se oferece como objeto de interpretação;

6. na norma jurídica, a busca de sentido do texto está vinculada à intencionalidade buscada por seu empreendedor, seja a implementação de específicos e identificáveis interesses ou a concretização da justiça;

7. interpretar implica na opção por um sentido da norma: aquele que é construído de acordo com as convicções do intérprete, seus interesses e seus compromissos ideológicos e ter consciência destas peculiaridades, condicionantes e limitadoras do ato interpretativo, é fundamental para se aventurar no universo hermenêutico e buscar o significado das normas;

8. discurso pode ser entendido como uma maneira de construir sentidos que influenciam e organizam as ações dos homens e as concepções que eles têm deles mesmos e do mundo e, como integrantes do discurso, os signos são estudados pela semiótica ou semiologia;

9. a semiótica é a ciência geral de todas as linguagens, estudando em conjunto as características lingüísticas, psicológicas, filosóficas e sociológicas dos sistemas comunicativos, sendo a ciência de toda e qualquer linguagem e o campo jurídico da realidade social, lidando com o discurso jurídico, conta com os recursos da semiótica jurídica, pois o direito exprime-se numa linguagem técnico-jurídica;

10. dentre as dimensões semióticas da norma jurídica releva a dimensão pragmática, que considera a norma sob o ponto de vista do emprego que dela fazem seus intérpretes e usuários, ou seja, a norma, suas significações e seus destinatários, onde estará presente a ideologia, por integrar a tarefa hermenêutica;

11. na qualidade de texto, a norma jurídica é uma composição pluralística: o legislador é o primeiro intérprete da realidade, estabelecendo a proposição normativa através do texto (que não se confunde com a norma: texto é o sinal lingüístico, enquanto a norma é aquilo que se revela) e o intérprete, partindo da primeira interpretação, perfaz a compreensão da norma, concretizando-a e, assim, legislador e intérprete compõem a norma em conjunto;

12. as normas resultam sempre da interpretação: as disposições e enunciados normativos formam o ordenamento em potência, como um conjunto de possibilidades de interpretação, desta maneira, o legislador registra proposições, e o intérprete compreende e compõe a norma;

13. toda interpretação jurídica é realizada sob a incidência de determinantes $e$ condicionantes que atuam simultaneamente sobre a atividade do intérprete: as 
determinantes são os fatores relacionados ao próprio intérprete, como ideologia, visão de mundo, posição social e demais interesses que direcionam sua atividade de busca do significado das normas jurídicas e as condicionantes estabelecem o que foi denominado horizonte interpretativo e firmam as balizas da interpretação ou, em outras palavras, condicionam os limites em que a interpretação pode estar contida;

14. nas normas jurídicas em geral, o horizonte interpretativo está estabelecido no curso de suas dimensões sintática (que informa sua relação e possibilidade de combinação com as demais normas do sistema jurídico, inclusive a Constituição), semântica (que expressa a conotação e a denotação dos termos da norma em relação ao objeto normado) e pragmática (que busca as funções da norma dentro do sistema, estando expressa nas denominações occasio legis [antecedentes] e ratio legis [finalidade], traduzidas como axiologia e teleologia normativa), sendo que a conjugação destas dimensões estabelece e condiciona os limites da interpretação;

15. na esteira da proposta de tridimensionalidade da norma jurídica na atividade interpretativa desenvolvida por FRIEDRICH MÜLLER, podemos vislumbrar que, diante do caso concreto, o intérprete está posto diante da seguinte problemática: o texto normativo da norma jurídica (enunciado) configura mera proposição ou norma de referência, não contendo imediatamente a norma, que surge apenas após a tarefa interpretativa (norma interpretada), configurando a norma a ser concretizada na hipótese que se apresenta, decidindo o caso concreto: o intérprete privilegiado é o magistrado, enquanto as partes e o MP também participam da tarefa interpretativa;

16. uma Constituição sempre estabelece uma nova idéia de direito em relação à anterior, podendo seu horizonte interpretativo ser descortinado como fator de transformação social, pois contêm seus dispositivos normas que, mesmo internalizadas como dimensão simbólica, podem ser concretizadas sob o viés de um compromisso com a mudança e a emancipação;

17. as relações entre o conteúdo da Constituição e a realidade social, onde se localizam seus destinatários, são necessariamente mediatizadas interpretativamente pelos operadores do direito e, imperando entre estes a visão dogmático-tradicional, o grau de eficácia e aplicabilidade de suas normas ficará comprometido com a manutenção do mundo existente, mesmo que a custo do esvaziamento de seu significado e da conservação de uma realidade profundamente injusta e indigna;

18. preconiza-se, então, uma abordagem da Constituição que edifique uma proposta emancipatória do homem e de dignificação da ordem jurídica, pois o direito intervém na realidade, transformando-a, dentro de certos limites;

19. propõe-se identificar, na interpretação das normas constitucionais, ao lado dos fatores relacionados ao próprio intérprete, como determinantes de uma interpretação em detrimento de outra(s), as condicionantes que se manifestam principalmente através da nova idéia de direito plasmada pelo constituinte 
originário, expressa nos princípios adotados (como os contidos no Preâmbulo, por exemplo) e nas regras estabelecidas, consistindo, em seu conjunto, no horizonte interpretativo da Constituição, em síntese, preconiza-se que o horizonte interpretativo da interpretação constitucional é estabelecido e condicionado pela nova idéia de direito fixada pelo constituinte originário;

20. a ADPF tem por objeto evitar ou reparar lesão a preceito fundamental, resultante de ato do Poder Público, cabendo também quando for relevante o fundamento da controvérsia constitucional sobre lei ou ato normativo federal, estadual ou municipal, incluídos os anteriores à Constituição;

21. o conceito de preceito fundamental decorrente da Constituição deve calcar-se na idéia de fundamentalidade de R. ALEXY, como se referindo a matérias decisivamente constitutivas das estruturas básicas do Estado e da sociedade, consistindo no sem o qual não, isto é, trata-se de normas tão marcadamente essenciais à estrutura social e estatal fixada pelo constituinte originário que, uma vez retiradas do texto, provocariam incompletude, mutilando o conjunto estabelecido, possuindo as seguintes especificidades identificadoras: a) refere-se a normas que se reportam às estruturas básicas do Estado Democrático de Direito que, embora estejam concentradas nos arts. $1^{\mathrm{O}} \mathrm{a}$ 17 , não se exaurem neste elenco; b) abrange, também, normas que disponham sobre estruturas básicas da sociedade, como família, educação, cultura e outras; dividindo-se em duas espécies: $\left.1^{\mathfrak{a}}\right)$ de natureza subjetiva, quando se refere a direitos que estão relacionados à dimensão dos indiví- duos, protegendo valores que consagram a vida, a liberdade e a dignidade; $2^{\text {a }}$ ) de natureza objetiva, quando seu conteúdo se refere ao interesse da coletividade e da sociedade, enfim, a valores que expressam a generalidade do interesse público;

22. a ADPF, apesar de possuir alguns pontos de semelhança com a ADIn, dela difere precipuamente por ter cabimento de forma preventiva (evitar lesão a preceito fundamental) ou corretiva (para reparar a lesão provocada), dirigindo-se contra ato do Poder Público, colhendo, neste particular, abrangência maior, alcançando um amplo leque de atividades e autoridades, inclusive as de natureza jurisdicional e, nesta perspectiva, a ADPF cobre um campo não abrangido pela ADIn, que visa apenas leis ou atos normativos federais ou estaduais;

23. quanto ao objetivo, deve ser entendido que a ADIn busca apenas a expulsão da lei ou ato inconstitucional do ordenamento jurídico, enquanto a ADPF, com a declaração de inconstitucionalidade, destina-se a pedidos de natureza preventiva e corretiva em relação aos preceitos fundamentais, buscando mais que o expurgo da norma;

24. na matéria em que couber a ADPF, também caberá a ADIn; mas, quando a pretensão consistir em evitar ou reparar lesão oriunda de descumprimento de preceito fundamental, não caberá a segunda, pois esta somente pode ser ajuizada contra lei ou ato normativo federal ou estadual em face de qualquer norma constitucional, buscando sua expulsão do ordenamento jurídico, enquanto a ADPF é pertinente apenas a preceitos fundamentais, à procura de prevenção ou reparação de lesão; 
25. a ADPF inclui o âmbito municipal nos embates entre leis e atos contrários à Constituição da República, o que está vedado no prisma da ADIn consoante farta jurisprudência do STF, embora esta inclusão seja especificamente em relação aos preceitos fundamentais; por outro lado, admite que sejam questionados atos do Poder Público anteriores a 1988, dando grande extensão ao seu alcance, não mais adstrito à esfera da vigência da Constituição, como na ADIn, na forma assentada pelo STF;

26. a efetivação destas possibilidades dependerá de como o STF entenderá o sentido de relevante fundamento da controvérsia constitucional, como previsto na Lei $\mathrm{n}^{\mathrm{o}}$
9.882/99 (art. 1ํㅡ, parágrafo único, inciso I);

27. a atribuição de vinculatividade às decisões definitivas na ADPF parece estigmatizada pela mácula da inconstitucionalidade material, uma vez que a imputação desta vinculação é dada por norma de escalão infraconstitucional, manejando, no entanto, matéria de essência constitucional, pois, por conferir tão grave atributo a estas decisões, a matéria é de competência constitucional, por consubstanciar característica básica e atípica (quer dizer, extraordinária) do próprio sistema judicial adotado, configurando, não sem certa iro nia, preceito fundamental. 